\title{
IS VITAMIN D NECESSARY FOR SKELETAL INTEGRITY IN THE ELDERLY?
}

\author{
S. P. THOMPSON, T. J. WILTON, D. J. HOSKING, D. A. WHITE, E. PAWLEY
}

From University Hospital Nottingham, and City Hospital, Nottingham

\begin{abstract}
Serum 1.25 dihydroxyvitamin D concentrations were reduced in elderly patients with femoral neck fractures, irrespective of the presence of osteomalacia. This reduction was not attributable to a decrease in vitamin $D$ binding protein. The low rate of bone turnover in these elderly patients might reduce the requirement for vitamin D and protect against the development of osteomalacia. Serum vitamin D metabolite concentration cannot be used as a screening test for osteomalacia in these patients.
\end{abstract}

Despite previous reports that osteomalacia is common among the elderly (Jenkins et al 1973; Aaron et al 1974), two recent surveys have shown that it is now rare in both acutely ill elderly patients (Campbell et al 1986) and those with femoral neck fractures (Wilton et al 1987a).

Does the declining frequency of osteomalacia reflect improved nutrition of the elderly or is there some other explanation? Improvement in nutrition seems unlikely since circulating concentrations of 25 hydroxyvitamin $D$ (25 OHD) seem to be low in this age group (Brown, Bakowska and Millard 1976; Weisman et al 1978; Baker et al 1979). The situation is especially confused with respect to 1.25 dihydroxyvitamin $\mathrm{D}\left(1.25(\mathrm{OH})_{2} \mathrm{D}\right)$ where circulating concentrations have been reported as being low, normal or high (Lips et al 1982; Francis et al 1984; Meller et al 1985; Hordon and Peacock 1987). The low prevalence of osteomalacia, despite abnormal plasma concentrations of vitamin D metabolites in patients with femoral neck fractures, seems paradoxical in view of the accepted role of vitamin $D$ in the maintenance of calcium and skeletal homoeostasis.

We have measured serum concentrations of the

S. P. Thompson, BSc(Hons), Research Student

D. A. White, PhD, Senior Lecturer

Department of Biochemistry

T. J. Wilton, BA, FRCS, Orthopaedic Senior Registrar

E. Pawley, FIMLS, Research Assistant

Department of Orthopaedic and Accident Surgery, University Hospital,

Queen's Medical Centre, Clifton Boulevard, Nottingham NG7 2UH,

England.

D. J. Hosking, MD, FRCP, Consultant Physician

Department of Medicine, City Hospital, Hucknall Road, Nottingham NG5 IPB, England.

Correspondence should be sent to Dr D. J. Hosking.

(C) 1990 British Editorial Society of Bone and Joint Surgery

$0301-620 X / 90 / 6203 \$ 2.00$

J Bone Joint Surg [Br] 1990; 72-B: 1053-6. hydroxylated metabolites of vitamin D in elderly patients at presentation with femoral neck fracture. Those with and without osteomalacia have been compared to assess the pathogenetic significance of vitamin D deficiency in this age group.

\section{PATIENTS AND METHODS}

The study formed part of a screening programme during 1984 to 1986 to detect subclinical osteomalacia complicating femoral neck fractures (Wilton et al 1987b). A peri-operative iliac crest bone biopsy was done in each patient and the findings were quantified as described by Kemm et al (1984). For our purposes, osteomalacia was defined as a biopsy showing a relative osteoid area greater than $5 \%$ and a trabecular osteoid surface of over $25 \%$ (Wilton et al 1987a).

Sixty-seven patients were studied (Table I): a random group of 31 had femoral neck fracture without osteomalacia (mean age 79 years, range 57 to 92), and 25 had femoral neck fracture complicated by osteomalacia (mean age 82 years, range 57 to 95 ). We included all patients in whom osteomalacia had been diagnosed and investigation of vitamin D metabolism had been possible. We also investigated 11 younger patients with osteomalacia but no fracture (mean age 48 years, range 43 to 58 ) who had been referred to the metabolic unit over the same period. Serum calcium, phosphate, creatinine, alkaline phosphatase and albumin were measured in fasting blood samples taken within 24 hours of admission. Separate samples for vitamin D and vitamin D binding protein (DBP) were obtained generally within a few days of admission. Hydroxylated metabolites of vitamin D were extracted from plasma and purified by straightphase, high-performance liquid chromatography. The 25 $\mathrm{OHD}$ and $1.25(\mathrm{OH})_{2} \mathrm{D}$ sample peaks were collected; 25 
OHD was measured by a competitive protein binding assay with a serum binding protein, and $1.25(\mathrm{OH})_{2} \mathrm{D}$ by a competitive protein binding assay with calf thymus cytosol (Reinhardt et al 1984). Vitamin D binding protein concentrations were measured by radial immunodiffusion (Bouillon, van Baelen and de Moor 1977).

Reference values for $25 \mathrm{OHD}, 1.25(\mathrm{OH})_{2} \mathrm{D}$ and DBP were derived from 26 healthy elderly controls (mean age 70 years, range 60 to 82 ) who were relatives of patients attending a metabolic out-patient clinic. These subjects appeared well and none was known to have renal, gastro-intestinal or musculoskeletal disease. Reference data were also derived from 42 healthy laboratory workers (mean age 34 years, range 18 to 54 ).

\section{RESULTS}

Figure 1 shows serum concentrations of $25 \mathrm{OHD}$ and $1.25(\mathrm{OH})_{2} \mathrm{D}$ for all the groups. The mean (SEM) serum $25 \mathrm{OHD}$ and $1.25(\mathrm{OH})_{2} \mathrm{D}$ concentrations of the 26 elderly controls were $32.1(3.7) \mathrm{nmol} / 1$ and $51.6(4.6) \mathrm{pmol} / \mathrm{l}$, respectively, and the corresponding values for the 42 young controls were $68.6(3.1) \mathrm{nmol} / \mathrm{l}$ and $82.9(3.2) \mathrm{pmol} /$ 1 (elderly controls versus young controls: 25 OHD $\mathrm{p}<0.02 ; 1.25(\mathrm{OH})_{2} \mathrm{D} \mathrm{p}<0.01$, Wilcoxon rank sum test). Vitamin D concentrations were predictably low in both young and elderly patients with osteomalacia. However, many elderly controls (no bone biopsy) and elderly fracture patients without osteomalacia had equally low levels of $25 \mathrm{OHD}$ and $1.25(\mathrm{OH})_{2} \mathrm{D}$. The concentrations of either vitamin $\mathrm{D}$ metabolite did not differ significantly between any of the elderly groups.

There was no correlation between $25 \mathrm{OHD}$ or
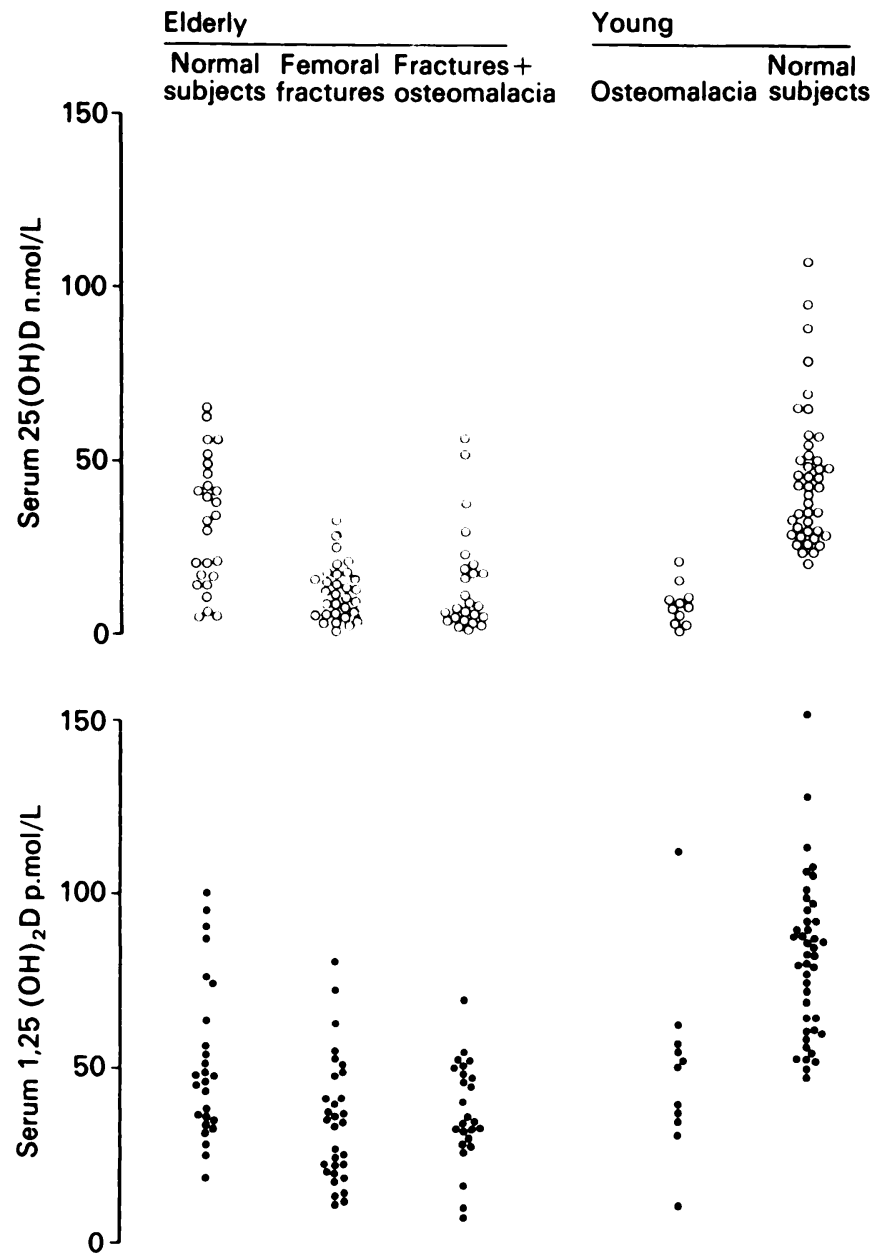

Fig. 1

Serum $25 \mathrm{OHD}$ and $1.25(\mathrm{OH})_{2} \mathrm{D}$ concentrations in elderly patients with fractures, controls, and young patients with osteomalacia.

Table I. Biochemical and histological indices* in patients according to presence of fracture and/or osteomalacia

\begin{tabular}{|c|c|c|c|c|c|c|c|c|}
\hline Patients & Number & $\begin{array}{l}\text { Calcium } \\
\text { (mmol/l) }\end{array}$ & $\begin{array}{l}\text { Phosphate } \\
\text { (mmol/l) }\end{array}$ & $\begin{array}{l}\text { Creatinine } \\
(\mu \mathrm{mol} / /)\end{array}$ & $\begin{array}{l}\text { Alkaline } \\
\text { phosphatase } \\
\text { (IU/f) }\end{array}$ & $\begin{array}{l}\text { Trabecular } \\
\text { bone } \\
\text { volume (\%) }\end{array}$ & $\begin{array}{l}\text { Relative } \\
\text { osteoid } \\
\text { area (\%) }\end{array}$ & $\begin{array}{l}\text { Relative } \\
\text { osteoid } \\
\text { surface (\%) }\end{array}$ \\
\hline \multicolumn{9}{|l|}{ Elderly } \\
\hline Intertrochanteric & 15 & $2.27(0.04)$ & $1.17(0.09)$ & $99(5)$ & $215(34)$ & $13.5(1.2)$ & $1.7(0.2)$ & $10.9(1.7)$ \\
\hline Subcapital & 16 & $2.16(0.04)$ & $0.92(0.07)$ & $100(7)$ & $212(34)$ & $15.2(1.7)$ & $1.4(0.2)$ & $7.3(1.1)$ \\
\hline osteomalacia & 25 & $2.16(0.04)$ & $0.88(0.05)$ & $112(10)$ & $571(118)$ & $18.7(1.8)$ & $19.0(2.5)$ & $55.6(4.1)$ \\
\hline \multicolumn{9}{|l|}{ Young } \\
\hline Osteomalacia & 11 & $1.95(0.08)$ & $0.92(0.09)$ & $97(13)$ & $563(112)$ & $20.6(1.9)$ & $31.6(5.9)$ & $68.4(8.0)$ \\
\hline
\end{tabular}

*expressed as mean (SEM)

$1.25(\mathrm{OH})_{2} \mathrm{D}$ and osteoid area or osteoid surface for any of the subgroups or for the total elderly population. Figure 2 shows the relation between $1.25(\mathrm{OH})_{2} \mathrm{D}$ and osteoid surface for the fracture patients without osteomalacia. Many of those with low levels of $1.25(\mathrm{OH})_{2} \mathrm{D}$ also had a low rate of bone turnover as assessed from the surface extent of osteoid, and this low turnover tended to be associated with hypocalcaemia.
Serum concentrations of $25 \mathrm{OHD}, 1.25(\mathrm{OH})_{2} \mathrm{D}$ and DBP can change more rapidly than the histomorphometric indices. To assess whether the interval between hospital admission and blood sampling was an important determinant of low $1.25(\mathrm{OH})_{2} \mathrm{D}$ concentration, DBP and $1.25(\mathrm{OH})_{2} \mathrm{D}$ were examined in relation to the time of blood sampling (Fig. 3). In neither was time an important variable. Measurements of DBP were only available in 
46 of 67 patients and in 19 of 26 elderly controls. In these patients there was a good correlation $(r=0.87$, $\mathrm{p}<0.001)$ between total and free $1.25(\mathrm{OH})_{2} \mathrm{D}$. Moreover, DBP and free $1.25(\mathrm{OH})_{2} \mathrm{D}$ index did not differ in any of the elderly subgroups, or between the elderly patients and the younger subjects with osteomalacia and no fracture.

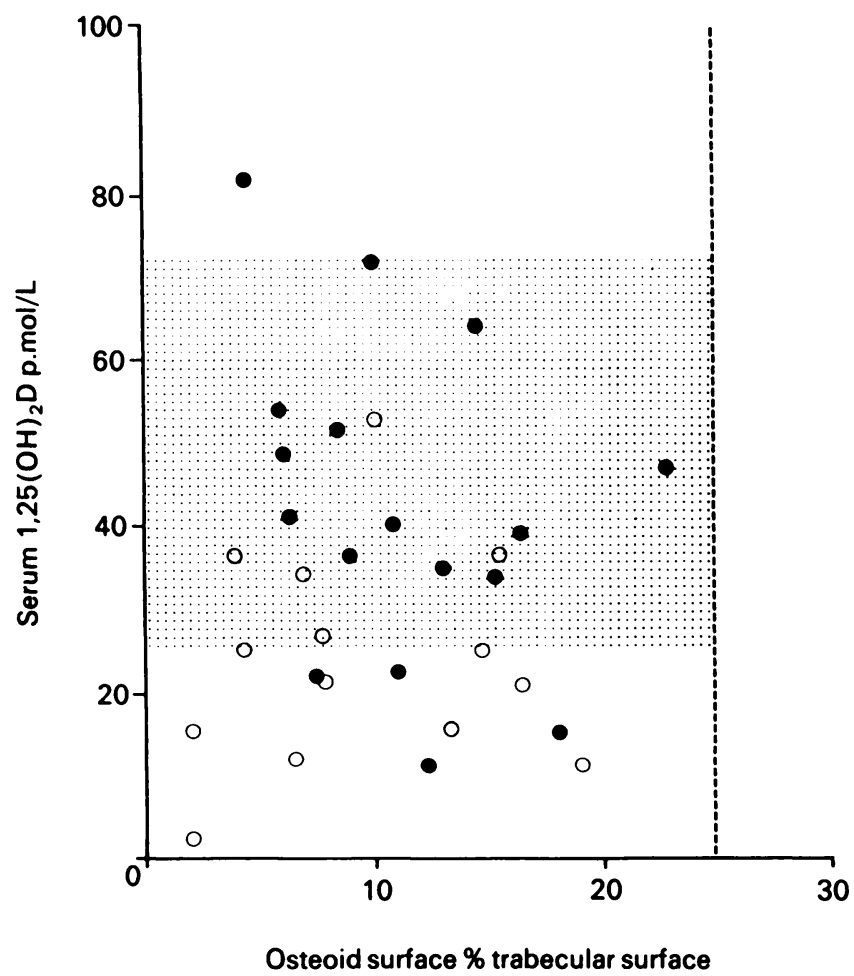

Fig. 2

Relations between serum 1.25(OH) $2 \mathrm{D}$ and bone turnover (extent of osteoid surface) in fracture patients without osteomalacia.

Serum calcium : $0<2.2 \mathrm{mmol} / 1 ; 0>2.2 \mathrm{mmol} / \mathrm{l}$. Shaded area $=$ normal range for elderly controls.

\section{DISCUSSION}

The assay we used gave a reference range for serum $1.25(\mathrm{OH})_{2} \mathrm{D}$ concentration for young healthy subjects of 50 to $150 \mathrm{pmol} / \mathrm{l}$. This range is closely similar to those reported by others (Fraher et al 1983; Mawer et al 1985; Hartwell and Christiansen 1988), although low values have been found in elderly patients (Lips et al 1982; Meller et al 1985). The observation that a significant proportion of elderly fracture patients without osteomalacia and some apparently healthy elderly controls had $1.25(\mathrm{OH})_{2} \mathrm{D}$ values as low as those in patients with osteomalacia was unexpected.

There are several possible explanations why low $1.25(\mathrm{OH})_{2} \mathrm{D}$ concentrations may not invariably be associated with osteomalacia. Vitamin $\mathrm{D}$ binding protein concentrations may be low immediately after femoral neck fracture (Lips et al 1982; Thompson et al 1989), although they generally recover within the subsequent week (Thompson et al 1989). However, most patients in the present study had normal DBP concentration, and the low $1.25(\mathrm{OH})_{2} \mathrm{D}$ concentrations are unlikely to result from reduced binding protein. Although DBP values were not available for every subject, the correlation between total $1.25(\mathrm{OH})_{2} \mathrm{D}$ and the free $1.25(\mathrm{OH})_{2} \mathrm{D}$
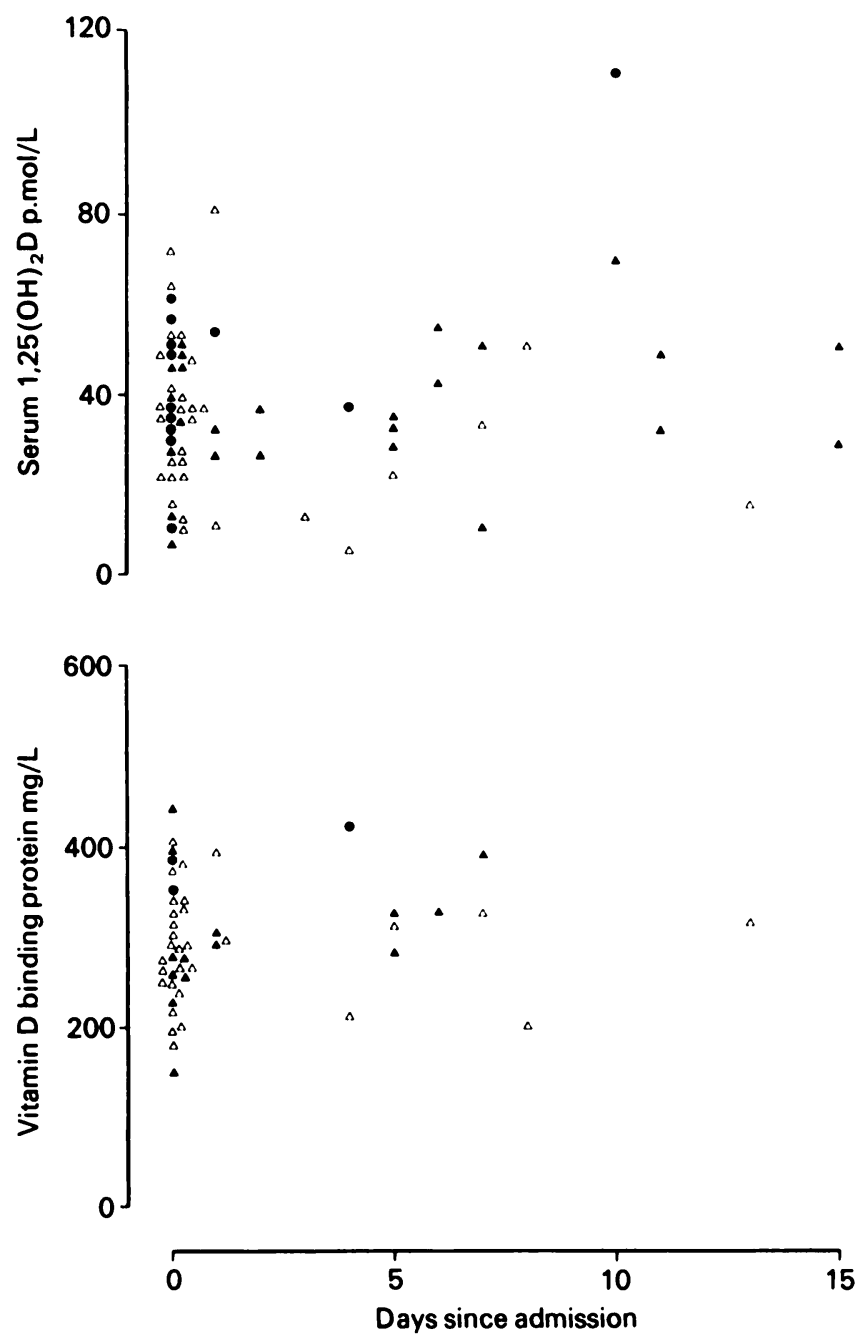

Fig. 3

Relations between serum $1.25(\mathrm{OH})_{2} \mathrm{D}$ and vitamin $\mathrm{D}$ binding protein and the delay between admission and sampling. $\triangle$ elderly patients with femoral neck fracture; $\Delta$ elderly patients with femoral neck fracture and osteomalacia; young (non-fracture) patients with osteomalacia.

index was so high that total $1.25(\mathrm{OH})_{2} \mathrm{D}$ values are probably reliable.

A more probable proposal is that the low $1.25(\mathrm{OH})_{2} \mathrm{D}$ concentration reflects the presence of type II osteoporosis, which may be an almost universal occurrence in the very old and commonly presents with proximal femoral fractures. This osteoporosis is characterised by decreased renal $25(\mathrm{OH}) \mathrm{D}-1 \alpha$-hydroxylase activity, leading to impaired $1.25(\mathrm{OH})_{2} \mathrm{D}$ production and reduced osteoblast 
activity (Riggs and Melton 1983). In this respect, the low values for the surface extent of trabecular osteoid we found would be consistent with decreased osteoblast function. It might be that in the presence of a low rate of bone formation, less $1.25(\mathrm{OH})_{2} \mathrm{D}$ than normal is needed for adequate mineralisation. Low turnover may in this sense protect against osteomalacia, although the fact that many of these patients were hypocalcaemic indicates impaired calcium homoeostasis that may be being mediated at the skeletal level by a decreased $1.25(\mathrm{OH})_{2} \mathrm{D}$ effect on osteoblast function (Parfitt 1987).

Our results have several practical implications. In the very old, the rate of activation of new bone remodelling units may be so low that vitamin $\mathrm{D}$ deficiency may need to be present for a very long time before osteoid accumulates to such an extent that it fulfils the generally accepted criteria for osteomalacia (Meunier 1983). Moreover, low turnover may be associated with a very slow response of osteomalacia to vitamin D therapy (Meunier 1983). Dietary supplementation with vitamin $\mathrm{D}$ in elderly people seems unlikely to improve bone structure unless there is overt osteomalacia. Whether long-term supplementation starting at an earlier age may improve bone mass, by offsetting the age-related decline in intestinal calcium absorption seen in the elderly (Baker, Peacock and Nordin 1980; Francis et al 1984), remains uncertain. Identification of patients with low serum $25 \mathrm{OHD}$ and $1.25(\mathrm{OH})_{2} \mathrm{D}$ concentrations cannot, alone, be equated with the presence of osteomalacia. Such measurements do not help to resolve the problem of eliminating the high false-positive rate associated with biochemical screening of fracture patients for the presence of occult osteomalacia (Wilton et al 1987b).

Our findings therefore suggest that the freedom of the very old from the presence of osteomalacia is attributable to their low rate of bone turnover, which protects them from the effects of $1.25(\mathrm{OH})_{2} \mathrm{D}$ deficiency.

Although none of the authors have received or will receive benefits for personal or professional use from a commercial party related directly or indirectly to the subject of this article, benefits have been or will be received but are directed solely to a research fund, foundation, educational institution, or other non-profit institution with which one or more of the authors is associated.

\section{REFERENCES}

Aaron JE, Gallagher JC, Anderson J, et al. Frequency of osteomalacia and osteoporosis in fractures of the proximal femur. Lancet 1974; i :229-33.

Baker MR, McDonnell H. Peacock M, Nordin BEC. Plasma 25-hydroxy vitamin $\mathrm{D}$ concentrations in patients with fractures of the femoral neck. Br Med J 1979; i:589.

Baker MR, Peacock M, Nordin BEC. The decline in vitamin D status with age. Age Ageing 1980; 9:249-52.

Bouillon R, van Baelen H, de Moor P. The measurement of the vitamin D-binding protein in human serum. J Clin Endocrinol Metab 1977; $45: 225-31$.

Brown IR, Bakowska A, Millard PH. Vitamin D status of patients with femoral neck fractures. Age Ageing 1976; 5:127-31.

Campbell GA, Hosking DJ, Kemm JR, Boyd RV. Timing of screening for osteomalacia in acutely ill elderly. Age Ageing 1986; 15:156-63.

Fraher LJ, Adami S, Clemens TL, Jones G, O'Riordan JLH. Radioimmunoassay of 1.25 -dihydroxyvitamin $\mathrm{D}_{2}$ : studies on the metabolism of vitamin $\mathrm{D}_{2}$ in man. Clin Endocrinol 1983; 19:151-65.

Francis RM, Peacock M, Taylor GA, Storer JH, Nordin BEC. Calcium malabsorption in elderly women with vertebral fractures. Clin Science 1984; 66:103-7.

Hartwell D, Christiansen C. Comparisons between two receptor assays for 1.25-dihydroxyvitamin D. Scand J Clin Lab Inv 1988; 48: 109-14.

Hordon LD, Peacock M. Vitamin D metabolism in women with femoral neck fracture. Bone and Mineral 1987; 2:413-26.

Jenkins DHR, Roberts JG, Webster D, Williams EO. Osteomalacia in elderly patients with fracture of the femoral neck: a clinicopathological study. J Bone Joint Surg [Br] 1973; 55-B:575-80.

Kemm JR, Campbell G, Cotton RE, Hosking DJ, Boyd RV. Osteoid in bones of elderly patients without bone disease. Age Ageing 1984; 13:144-51.
Lips P, Netelenbos JC, Jongen MJM, et al. Histomorphometric profile and vitamin D status in patients with femoral neck fracture. Metab Bone Dis Relat Res 1982; $4: 85-93$.

Mawer EB, Klass HJ, Warnes TW, Berry JL. Metabolism of vitamin $D$ in patients with primary biliary cirrhosis and alcoholic liver disease. Clin Science 1985; 69:561-70.

Meller Y, Kestenbaum RS, Shany S, et al. Parathormone, calcitonin and vitamin D metabolites during normal fracture healing in geriatric patients. Clin Orthop 1985; 199:272-9.

Meunier PJ. Histomorphometry of the skeleton. In: Peck WA, ed. Bone and mineral research. Annual 1. Amsterdam, etc: Excerpta Medica, 1983:191-222.

Parfitt AM. Bone and plasma calcium homeostasis. Bone 1987 ; 8(Suppl. 1):S1-8.

Reinhardt TA, Horst RL, Orf JW, Hollis BW. A microassay for 1.25 dihydroxyvitamin $\mathrm{D}$ not requiring high performance liquid chromatography: application to clinical studies. J Clin Endocrinol Metab 1984; 58:91-8.

Riggs BL, Melton LJ III. Evidence for two distinct syndromes of involutional osteoporosis. Am J Med 1983; 75 :899-901.

Thompson SP, White DA, Hosking DJ, Wilton TJ, Pawley E. Changes in osteocalcin after femoral neck fractures. Ann Clin Biochem 1989; $26: 487-91$

Weisman Y, Salama R, Harell A, Edelstein S. Serum 24,25-dihydroxyvitamin $\mathbf{D}$ and 25 -hydroxyvitamin $\mathrm{D}$ concentrations in femoral neck fracture. $\mathrm{Br}$ Med J 1978; ii:1196-7.

Wilton TJ, Hosking DJ, Pawley E, Stevens A, Harvey L. Osteomalacia and femoral neck fractures in the elderly. J Bone Joint Surg [Br] 1987a; 69-B :388-90.

Wilton TJ, Hosking DJ, Pawley E, Stevens A, Harvey L. Screening for osteomalacia in elderly patients with femoral neck fractures. $J$ Bone Joint Surg [ Br] 1987b; 69-B :765-8. 